\title{
Prevalence and risk factors of work related asthma by industry among United States workers: data from the third national health and nutrition examination survey (1988-94)
}

\author{
A A Arif, L W Whitehead, G L Delclos, S R Tortolero, E S Lee
}

Occup Environ Med 2002;59:505-511

See end of article for authors' affiliations

Correspondence to Dr G L Delclos, University of Texas-Houston, School of Public Health, 1200 Herman Pressler Street, Suite RAS W1018, Houston, TX-77030, USA; gdelclos@sph.uth.tmc.edu

Accepted

17 October 2001

\begin{abstract}
Objectives: To estimate the prevalence of work related asthma and work related wheezing in United States workers. To identify high risk industries that could be targeted for future intervention. To determine the population attributable risk of work related asthma and work related wheezing.

Methods: The third national health and nutrition examination survey, 1988-1994 (NHANES III) was analyzed to determine the prevalence of work related asthma and wheezing and to identify initially defined industries at risk among United States workers aged 20 and older. Separate logistic models were developed with work related asthma and work related wheezing as outcomes. Work related asthma was defined as affirmative response to questions on self reported physician diagnosed asthma and work related symptoms of rhinitis, conjunctivitis, and asthma. Work related wheezing was defined as affirmative response to questions on self reported wheezing or whistling in the chest in the previous 12 months and work related symptoms of rhinitis, conjunctivitis, and asthma. All analyses were adjusted for age, sex, smoking, and atopy.

Results: The prevalence of work related asthma was $3.70 \%(95 \%$ confidence interval $(95 \% \mathrm{CI}) 2.88$ to 4.52 ) and the prevalence of work related wheezing was $11.46 \%(95 \% \mathrm{Cl} 9.87$ to 13.05$)$. The main industries identified at risk of work related asthma and wheeze included the entertainment industry; agriculture, forestry, and fishing; construction; electrical machinery; repair services; and lodging places. The population attributable risk for work related asthma was $36.5 \%$ and work related wheezing was $28.5 \%$.

Conclusions: The findings provide impetus for further research and actions by public health professionals which prioritise occupational asthma on the public health agenda. Future intervention strategies need to be developed for effective control and prevention of asthma in the workplace.
\end{abstract}

O ccupational asthma (OA) presently is the most often reported diagnosis of work related occupational respiratory disease in developed nations, and over 250 workplace agents have been identified as specific causes of OA. ${ }^{1}$ The national occupational exposure survey (1980-2) estimated that about $24 \%$ of the total workforce, employed in the United States industries, was exposed to occupational asthmagens. ${ }^{2}$ In the United Kingdom surveillance of work related and occupational respiratory diseases (SWORD) project, OA accounted for $26 \%$ of reported occupational lung disease, ${ }^{3}$ whereas in British Columbia, OA made up 52\% of reported occupational lung disease. ${ }^{4}$ Gannon et al reported an annual incidence of OA of 43/million among workers in the West Midlands region in the United Kingdom. ${ }^{5}$ It is estimated that, in the United States, there are over 20 million workers potentially exposed to occupational asthmagens; 9 million of these are exposed to established sensitisers and irritants. ${ }^{6}$ Estimates of the proportion of asthma that is attributed to workplace exposures vary widely, probably due to several factors, including lack of recognition of occupational factors, ${ }^{7}$ a general absence of statewide surveillance systems for asthma, ${ }^{8}$ variations in the case definitions for OA, and differences among denominator populations. Thus, anywhere from $2 \%$ to $36 \%$ of all adult asthma has been attributed to OA, both in the United States and other developed nations. ${ }^{7-12}$ In a recent review of 43 attributable risk estimates, Blanc and Toren ${ }^{13}$ found the median (range) value for attributable risk of occupationally related asthma to be $9 \%(2 \%-33 \%)$.

Certain occupational groups are known to be at particularly high risk of developing OA, including western red cedar workers, ${ }^{1}$ chemical workers exposed to isocyanate,${ }^{14}$ construction workers, ${ }^{15}$ bakers, and cleaners, ${ }^{16}$ textile workers, ${ }^{17}$ animal handlers, ${ }^{18}$ and healthcare workers. ${ }^{19}$

However, to our knowledge, no national estimates of the association between asthma and asthmatic symptoms with industry are available in the United States. The national health and nutrition examination survey (NHANES) provides a rich population based dataset to identify high risk industries. This study analysed data gathered from the third NHANES (NHANES III) to estimate the prevalence of work related asthma and wheezing, describe workers at high risk of developing asthma and asthma-like symptoms, and identify high risk industries that could be targeted for future intervention.

\section{MATERIALS AND METHODS}

The NHANES III was conducted in 1988-94, by the National Center for Health Statistics, to collect data on the health and nutrition of a representative sample of the non-institutionalised United States population. Detailed descriptions of the sampling strategy have been described elsewhere. ${ }^{20}$ Briefly stated, a stratified cluster sampling design was used to gather information on the health of about 40000 Americans, aged 2 months and older with no preset upper age limit.

Abbreviations: OA, occupational asthma; SWORD, United Kingdom surveillance of work related and occupational respiratory diseases; NHANES III, national health and nutrition examination survey III; PAR, population attributable risk 


\begin{tabular}{|c|c|c|}
\hline Code & Abbreviations & Industries (1980 census codes) \\
\hline 1 & Administration and finance ${ }^{\star} \dagger$ & $\begin{array}{l}\text { Banking and other finance, Insurance and real estate; social services; except } \\
\text { justice, public order, and safety }(700-712,861-871,900-901,921-932)\end{array}$ \\
\hline 2 & Agriculture, forestry and fishing $\ddagger$ & Agriculture production and agricultural services, forestry, and fishing (010-031) \\
\hline 3 & Mining & Mining (040-050) \\
\hline 4 & Construction & Construction (060) \\
\hline 5 & Food and kindred products & Food and kindred products (100-122) \\
\hline 6 & Textile mill products§ & Textile mill products, apparel, and other finished textile products (132-152) \\
\hline 8 & Paper products, printing, and publishing & Paper products, printing, publishing, and allied industries (160-172) \\
\hline 9 & Chemicals, petroleum, and coal products & Chemicals, petroleum, and coal products $(180-201)$ \\
\hline 10 & Rubber, plastics, and leather products & Rubber, plastics, and leather products (210-222) \\
\hline 11 & Lumber and wood products & Lumber and wood products, including furniture (230-242) \\
\hline 12 & 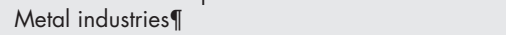 & Metal industries; machinery, except electrical (270-332) \\
\hline 14 & Electrical machinery, equipment, and supplies** & $\begin{array}{l}\text { Electrical machinery, equipment, and supplies; miscellaneous and not specified } \\
\text { manufacturing industries }(340-350,391-392)\end{array}$ \\
\hline 15 & Transportation equipment & Transportation equipment $(351-370)$ \\
\hline 17 & Trucking and transportation $\dagger \dagger$ & Trucking service; transportation, except trucking (400-432) \\
\hline 19 & Communications & Communications (440-442) \\
\hline 20 & Utilities & Utilities (460-472) \\
\hline 21 & Wholesaleł & $\begin{array}{l}\text { Wholesale trade, durable goods; wholesale trade, non-durable and not specified } \\
\text { goods }(500-571)\end{array}$ \\
\hline 23 & Retail trade§§ & $\begin{array}{l}\text { Department stores, food stores, vehicle dealers, supply and service stores, apparel } \\
\text { and accessory stores and other retail trade }(580-631,642-691)\end{array}$ \\
\hline 27 & Eating and drinking places & Eating and drinking places (641) \\
\hline 31 & Business services $\llbracket$ ๆ & Business services, other professional and related services $(721-750,882-892)$ \\
\hline 32 & Repair services & $\begin{array}{l}\text { Automotive repair and related services, electrical repair shops, miscellaneous } \\
\text { repair services }(751-760)\end{array}$ \\
\hline 33 & Private households & Private households (761) \\
\hline 34 & Lodging places & Lodging places (762-770) \\
\hline 35 & Personal services & Personal services, except private households and lodging (771-791) \\
\hline 36 & Entertainment and recreation services & Entertainment and recreation services (800-802) \\
\hline 37 & Health related $* * *$ & $\begin{array}{l}\text { Offices of health practitioners, hospitals, health services, not elsewhere classified } \\
(812-840)\end{array}$ \\
\hline 40 & Educational services & Educational services $(842-860)$ \\
\hline 43 & Justice, public order and safety & Justice, public order, and safety (910) \\
\hline
\end{tabular}

*Referent category; †NHANES III codes 29,30,41, and 44 combined and recoded as code 1; †NHANES III codes 1 and 2 combined and recoded as code 2; §NHANES III codes 6 and 7 combined and recoded as code 6 ; 9 NHANES III codes 12 and 13 combined and recoded as code 12; **NHANES

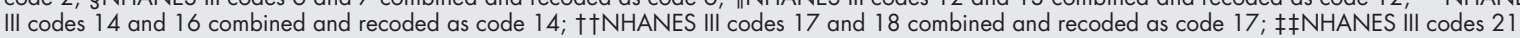
and 22 combined and recoded as code 21; §£NHANES III codes 23-26 and 28 combined and recoded as code 23; I 9 NHANES III codes 31 and 42 combined and recoded as code $31 ; * * *$ NHANES III codes 37-39 combined and recoded as code 37.

\section{Definitions of variables}

Due to the variable nature of asthma and in the absence of any gold standard, diagnosis of asthma and OA becomes very difficult. There were no direct questions asked in the NHANES III project to assess the proportion of asthma related to workplace exposure. We therefore constructed two working definitions of work related asthma: (a) physician diagnosed work related asthma (work related asthma), based on responses in the affirmative to both questions, "has a doctor ever told you that you had asthma?" (Question HAClE) and "are any of the symptoms wheezing, whistling, stuffy, itchy, or runny nose, watery, itchy eyes brought on by work environment?" (Hereby referred to as work related conjunctivits, rhinitis, or asthma; question HAL14D); and (b) symptom based on work related asthma (work related wheezing), based on those who responded in the affirmative to both questions, "have you had wheezing or whistling in your chest at any time in the past 12 months? (item HAL6)" and "are any of the symptoms: wheezing, whistling, stuffy, itchy, or runny nose, watery, itchy eyes brought on by work environment? (item HAL14D)".

Based on the response to the question on work related conjunctivits, rhinitis, or asthma (item HAL14D), a subset of 10391 subjects from the NHANES III dataset was selected. People who responded that they were not working at the time of interview $(n=3564)$ were excluded, leaving the total sample size of 6827 . The variable used to define work related asthma was created by combining only those subjects who responded in the affirmative $(n=188)$ and in the negative $(n=4834)$ to both HACIE and HALl4D for the total sample of 5022. A similar concordant pair approach was used to define work related wheezing and yielded a sample of 4573, which was included in the final analysis. Thus, the final sample included 188 cases of work related asthma and 454 cases of work related wheezing.

Other variables included in the analysis were atopy (defined as an affirmative response to the question "has a doctor ever told you that you had hay fever?"), smoking (non-smokers, past smokers, and current smokers), race or ethnicity (non-hispanic whites, non-hispanic blacks, MexicanAmericans, and other), and poverty income ratio (below poverty level, above poverty level). The poverty income ratio was computed as a ratio of the annual family income as the numerator and the poverty threshold, the age of the family reference person, and the calendar year in which the family was interviewed as the denominator.

\section{Definition of industry categories}

The NHANES III questionnaire included a comprehensive section on occupational history. Questions related to the longest industry in which the person worked (item HAS19R) were asked of all adult study subjects interviewed during the survey. The longest industry of work was defined as, "what kind of business or industry did you work in the longest time?" Originally, industrial categories were classified based on categories defined by the 1980 United States Bureau of the Census. ${ }^{21}$ The longest held industry information was available for 6557 (96.04\%) eligible subjects. Among the cases with work related asthma, occupational history was available for 185 (98\%) subjects and among those with work related wheezing, occupational history was available for 438 (96.5\%) subjects.

In the NHANES III dataset, longest worked industrial categories were originally aggregated into 44 industrial sets. In this study these were further collapsed into 28 based on 
Table 2 Characteristics of the NHANES III adult study population (1988-94)

\begin{tabular}{|c|c|c|}
\hline \multirow[b]{2}{*}{ Variable } & \multicolumn{2}{|c|}{ Total $(n=6827)$} \\
\hline & $\mathrm{n}^{*}$ & $\%$ (Weighted) \\
\hline \multicolumn{3}{|l|}{ Sex: } \\
\hline Male & 3365 & 50.30 \\
\hline Female & 3462 & 49.70 \\
\hline Age (mean (SE)) & \multicolumn{2}{|c|}{$39.58(0.34)$} \\
\hline \multicolumn{3}{|l|}{ Race or ethnicity: } \\
\hline Non-hispanic white & 3124 & 81.10 \\
\hline Non-hispanic black & 1841 & 8.84 \\
\hline Mexican American & 1614 & 3.93 \\
\hline Other & 248 & 6.13 \\
\hline \multicolumn{3}{|l|}{ Poverty income ratio: } \\
\hline Below poverty & 993 & 9.30 \\
\hline Above poverty & 5311 & 90.70 \\
\hline \multicolumn{3}{|l|}{ Smoking: } \\
\hline Non-smokers & 3245 & 45.21 \\
\hline Current smokers & 1994 & 31.43 \\
\hline Past smokers & 1588 & 23.35 \\
\hline \multicolumn{3}{|l|}{ Atopy $\uparrow$ by age group: } \\
\hline All age & $1009 / 6826$ & 17.46 \\
\hline $20-29$ & $199 / 1532$ & 13.02 \\
\hline $30-39$ & $287 / 1397$ & 21.31 \\
\hline $40-49$ & $246 / 1131$ & 20.14 \\
\hline $50-59$ & $151 / 773$ & 16.38 \\
\hline$\geqslant 60$ & $126 / 984$ & 13.64 \\
\hline
\end{tabular}

*Total may not add up to 6827 due to missing values; †atopy was defined as an affirmative response to a question "has a doctor ever told you that you had hay fever?"

review by an industrial hygienist (table 1) to have an optimal number of observations in each industrial group for meaningful statistical analysis. The industrial hygienist was blinded to the subject's asthma status.

A referent industry category was defined at the outset. Referent categories were constructed by collapsing industry categories where the potential of exposure to asthmagens were minimal and included "banking and other finance" (code 29); "insurance and real estate" (code 30); "social services" (code 41); and "public administration, except justice, public order, and safety" (code 44)". All other industries, not included in the referent category, were considered to be at risk.

\section{Statistical analysis}

Due to the complex multistage survey design used in the NHANES III, STATA statistical software (STATA, College Station, TX), which allows incorporation of sampling weights, strata, and primary sampling units, was used to analyze the data. The sampling weights include adjustments for nonresponse and unequal probability of selection used in the sampling design. Simple descriptive statistics were used to describe the study population and calculate the prevalences, expressed as percentages, of work related asthma and wheeze, followed by multivariate logistic regression analysis to explore the association between each industry group and the outcome variable. All odds ratios (ORs) calculated were initially adjusted for age, sex, race or ethnicity, poverty income ratio, atopy, and smoking. However, addition of race or ethnicity and poverty income ratio in the model did not change the OR significantly and were removed from the final analysis to keep the model simple.

The population attributable risk (PAR) was calculated separately for work related asthma and work related wheezing using the following formula:

$\mathrm{PAR}=\mathrm{Pe}(\mathrm{OR}-1) / \mathrm{OR}$

where $\mathrm{Pe}=$ prevalence of exposure among cases (industrial categories was used as a surrogate measure of exposure); $\mathrm{OR}=\mathrm{ORs}$ for at risk industries. The ORs were adjusted for age, sex, atopy, and smoking. For calculation of PAR, the initially defined referent category was used as a low risk industrial category and all other industrial groups were categorised as at risk industries (table 1).

\section{RESULTS}

Table 2 shows the general demographic characteristics of the study population. The estimated prevalences of work related asthma and work related wheezing were 3.7\% and $11.5 \%$ respectively. The prevalence of atopy was highest in the age group 30-49. When restricted to the age group 20 to 44 years, the prevalence rates of work related asthma and wheeze did not change significantly (3.8\% and $13 \%$ respectively, table 3 ). The overall prevalence of medically diagnosed asthma, wheezing, and work related symptoms of wheezing, conjunctivitis, rhinitis, and asthma are shown in table 3. Table 4 shows prevalence of work related asthma and wheeze by selected characteristics. Atopic people have a higher prevalence of work related asthma and wheeze than non-atopic people. Current smokers have a higher prevalence of work related wheeze than non-smokers and ex-smokers. However, no differences were found for work related asthma.

\section{Risk of work related asthma by industry}

Table 5 presents a summary of risk of work related asthma. There were considerable variations in risk by industry. The prevalence and ORs of association with work related asthma were only significantly increased for the entertainment industry (OR $5.96,95 \%$ CI 1.58 to 22.45 ). However, a greater than two-fold increase in risk was found for agriculture, forestry and fishing; rubber, plastics, and leather products; lumber and wood products; electrical machinery; transportation equipment and trucking; wholesale trade; repair services; health related services; educational services; and justice, public order, and safety industries.

\section{Risk of work related wheezing by industry}

The estimated prevalence and ORs of wheezing were significantly increased for five industries (table 6). These included agriculture, forestry and fishing (OR 2.67, 95\% CI 1.44 to 4.97 ); construction (OR $3.11,95 \%$ CI 1.49 to 6.47 ); electrical machinery (OR 2.25, 95\% CI 1.02 to 4.95 ); repair services (OR 3.35, 95\% CI 1.35 to 8.33 ); and lodging places (OR $4.10,95 \%$ CI 1.39 to 12.114). The odds of association with work related wheezing

Table 3 Prevalence $(95 \% \mathrm{Cl})$ of outcome variables used in the analysis of the NHANES III data (1988-94)

\begin{tabular}{|c|c|c|c|c|}
\hline \multirow[b]{2}{*}{ Variable } & \multicolumn{2}{|c|}{ Age group $\geqslant 20$} & \multicolumn{2}{|c|}{ Age group 20-44 } \\
\hline & $\%$ & $95 \% \mathrm{Cl}$ & $\%$ & $95 \% \mathrm{Cl}$ \\
\hline Work related asthma* & 3.70 & 2.88 to 4.52 & 3.83 & 2.83 to 4.84 \\
\hline Medically diagnosed asthma (HAC IE)† & 9.70 & 8.51 to 10.90 & 9.85 & 8.59 to 11.11 \\
\hline Work related wheezing $\ddagger$ & 11.46 & 9.87 to 13.05 & 13.09 & 11.06 to 15.13 \\
\hline Wheezing (HAL6)† & 25.53 & 23.89 to 27.17 & 25.67 & 23.75 to 27.59 \\
\hline
\end{tabular}

*Work related asthma was created by combining affirmative responses to HAC1E and HAL14D as described in methods section; †HAC 1E, HAL6, corresponds to the number of the question in the NHANES III dataset as described in the methods section; fwork related wheezing was created by combining affirmative responses to HAL6 and HAL14D as described in methods section. 
Table 4 Prevalence of the work related asthma and work related wheezing by selected characteristics in the NHANES III adult study population (1988-94)

\begin{tabular}{|c|c|c|c|c|c|c|}
\hline & \multicolumn{3}{|c|}{ Work related asthma $(n=5022)$} & \multicolumn{3}{|c|}{ Work related wheezing $(n=4573)$} \\
\hline & $\mathrm{n}^{*}$ & $\% \dagger$ & $95 \% \mathrm{Cl}$ & $\mathrm{n}^{*}$ & $\% \dagger$ & $95 \% \mathrm{Cl}$ \\
\hline \multicolumn{7}{|l|}{ Sex: } \\
\hline Male & 2435 & 3.27 & 2.28 to 4.26 & 2195 & 13.32 & 10.73 to 15.9 \\
\hline Female & 2587 & 4.09 & 2.81 to 5.37 & 2378 & 9.66 & 7.95 to 11.36 \\
\hline \multicolumn{7}{|l|}{ Age groups: } \\
\hline $20-29$ & 1227 & 2.90 & 1.33 to 4.47 & 1166 & 14.73 & 11.77 to 17.70 \\
\hline $30-39$ & 1215 & 3.81 & 2.53 to 5.10 & 1130 & 11.33 & 8.73 to 13.94 \\
\hline $40-49$ & 951 & 4.92 & 2.82 to 7.01 & 890 & 12.66 & 8.91 to 16.42 \\
\hline $50-59$ & 703 & 4.89 & 3.11 to 6.67 & 610 & 8.78 & 6.70 to 10.86 \\
\hline$\geqslant 60$ & 926 & 1.10 & -0.07 to 2.26 & 777 & 3.84 & 1.51 to 6.17 \\
\hline \multicolumn{7}{|l|}{ Race or ethnicity: } \\
\hline Non-hispanic white & 2352 & 3.69 & 2.71 to 4.68 & 2137 & 12.11 & 10.14 to 14.08 \\
\hline Non-hispanic black & 1346 & 4.02 & 2.96 to 5.07 & 1226 & 7.90 & 6.44 to 9.35 \\
\hline Mexican American & 1135 & 3.88 & 3.00 to 4.76 & 1037 & 10.85 & 8.87 to 12.83 \\
\hline Other & 189 & 3.22 & 0.98 to 5.47 & 173 & 8.43 & 3.59 to 13.27 \\
\hline \multicolumn{7}{|l|}{ Poverty income ratio: } \\
\hline Below poverty & 741 & 4.54 & 2.15 to 6.92 & 628 & 14.76 & 8.56 to 20.93 \\
\hline Above poverty & 3892 & 3.74 & 2.81 to 4.68 & 3584 & 11.41 & 9.52 to 13.29 \\
\hline \multicolumn{7}{|l|}{ Atopy: } \\
\hline No & 4360 & 1.99 & 1.32 to 2.65 & 3922 & 10.18 & 8.66 to 11.69 \\
\hline Yes & 661 & 12.75 & 8.65 to 16.84 & 650 & 17.68 & 13.91 to 21.42 \\
\hline \multicolumn{7}{|l|}{ Smoking: } \\
\hline Non-smokers & 2405 & 3.30 & 2.23 to 4.37 & 2302 & 6.43 & 5.03 to 7.83 \\
\hline Current smokers & 1432 & 4.52 & 3.33 to 5.71 & 1179 & 23.42 & 19.43 to 27.41 \\
\hline Past smokers & 1185 & 3.45 & 2.05 to 4.85 & 1092 & 8.22 & 5.97 to 10.48 \\
\hline
\end{tabular}

were also more than two-fold higher for textile mill products; rubber, plastics, and leather products; transportation equipment; communications; and entertainment and recreation services. A significantly lower risk was found for the industrial group that included chemicals, petroleum, and coal products (OR $0.19 ; 95 \%$ CI 0.05 to 0.81 ). However, results were based on only three cases.
Population attributable risk

There were 185 cases of work related asthma and 437 cases of work related wheezing identified with occupational history. Of the 185 cases of work related asthma, $163(89.45 \%)$ worked in the at risk industries. Among the 437 cases of work related wheezing, 392 (90.47\%) worked in the at risk industries. The ORs of association for industries initially defined as at risk

Table 5 Estimated prevalence and OR $(95 \% \mathrm{Cl})$ of work related asthma by industry in the NHANES III adult study population (1998-4)

\begin{tabular}{|c|c|c|c|c|c|c|}
\hline Codes & Industry & Cases* & Prevalence (\%) & SE (\%) & OR & $95 \% \mathrm{Cl}$ \\
\hline 1 & Administration and finance $\dagger$ & 22 & 2.97 & 1.00 & 1.00 & - \\
\hline 2 & Agriculture, forestry, and fishing & 12 & 4.99 & 2.24 & 2.94 & 0.95 to 9.15 \\
\hline 3 & Mining & 1 & 1.04 & 1.04 & 0.68 & 0.06 to 7.60 \\
\hline 4 & Construction & 9 & 1.46 & 0.67 & 0.68 & 0.23 to 2.03 \\
\hline 5 & Food and kindred products & 5 & 1.86 & 1.25 & 0.74 & 0.14 to 3.80 \\
\hline 6 & Textile mill products & 7 & 2.41 & 1.00 & 1.58 & 0.45 to 5.59 \\
\hline 8 & Paper products, printing, and publishing & 3 & 2.24 & 1.85 & 1.24 & 0.18 to 8.47 \\
\hline 9 & Chemicals, petroleum, and coal products & 0 & 0.00 & 0.00 & - & - \\
\hline 10 & Rubber, plastics, and leather products & 1 & 3.87 & 2.97 & 2.29 & 0.28 to 18.69 \\
\hline 11 & Lumber and wood products & 1 & 4.48 & 4.30 & 2.84 & 0.27 to 30.13 \\
\hline 12 & Metal industries & 6 & 3.34 & 1.54 & 1.81 & 0.43 to 7.56 \\
\hline 14 & Electrical machinery, equipment, and supplies & 5 & 5.22 & 1.83 & 2.92 & 0.83 to 10.30 \\
\hline 15 & Transportation equipment & 4 & 4.68 & 1.13 & 2.10 & 0.63 to 7.02 \\
\hline 17 & Trucking and transportation & 9 & 5.13 & 2.22 & 2.44 & 0.73 to 8.10 \\
\hline 19 & Communications & 3 & 4.50 & 2.84 & 1.24 & 0.28 to 5.41 \\
\hline 20 & Utilities & 4 & 1.46 & 0.80 & 1.00 & 0.21 to 4.63 \\
\hline 21 & Wholesale & 10 & 5.01 & 1.79 & 2.01 & 0.64 to 6.28 \\
\hline 23 & Retail & 18 & 3.03 & 0.91 & 1.18 & 0.46 to 3.06 \\
\hline 27 & Eating and drinking places & 6 & 0.95 & 0.49 & 0.41 & 0.10 to 1.60 \\
\hline 31 & Business services & 8 & 3.41 & 1.26 & 1.31 & 0.52 to 3.32 \\
\hline 32 & Repair services & 2 & 5.48 & 3.82 & 2.83 & 0.55 to 14.62 \\
\hline 33 & Private households & 1 & 0.36 & 0.38 & 0.12 & 0.01 to 1.86 \\
\hline 34 & Lodging places & 2 & 1.66 & 1.23 & 0.75 & 0.13 to 4.41 \\
\hline 35 & Personal services & 1 & 1.74 & 1.74 & 0.86 & 0.08 to 8.82 \\
\hline 36 & Entertainment and recreation services & 4 & 8.92 & 4.70 & 5.96 & 1.58 to 22.45 \\
\hline 37 & Health related & 21 & 6.02 & 1.82 & 2.18 & 0.79 to 6.08 \\
\hline 40 & Educational services & 16 & 6.07 & 2.15 & 2.54 & 0.94 to 6.86 \\
\hline 43 & Justice, public order, and safety & 4 & 9.68 & 5.63 & 3.63 & 0.75 to 17.65 \\
\hline
\end{tabular}

*Total number of observed cases=185, three cases had missing information on occupational history and were not included in the analysis; †referent group. 
Table 6 Estimated prevalence and OR $(95 \% \mathrm{Cl})$ of work related wheezing by industry in the NHANES III adult study population (1998-4)

\begin{tabular}{|c|c|c|c|c|c|c|}
\hline Codes & Industry & Cases* & Prevalence (\%) & SE (\%) & OR & $95 \% \mathrm{Cl}$ \\
\hline 1 & Administration and finance $\dagger$ & 46 & 8.18 & 1.51 & 1.00 & - \\
\hline 2 & Agriculture, forestry, and fishing & 27 & 17.12 & 3.33 & 2.67 & 1.44 to 4.97 \\
\hline 3 & Mining & 3 & 2.55 & 2.02 & 0.27 & 0.04 to 1.66 \\
\hline 4 & Construction & 34 & 25.05 & 5.28 & 3.11 & 1.49 to 6.47 \\
\hline 5 & Food and kindred products & 8 & 3.54 & 2.34 & 0.34 & 0.08 to 1.48 \\
\hline 6 & Textile mill products & 22 & 14.00 & 4.72 & 2.19 & 0.92 to 5.22 \\
\hline 8 & Paper products, printing, and publishing & 6 & 9.97 & 4.71 & 1.30 & 0.41 to 4.14 \\
\hline 9 & Chemicals, petroleum, and coal products & 3 & 1.50 & 1.07 & 0.19 & 0.05 to 0.81 \\
\hline 10 & Rubber, plastics, and leather products & 3 & 15.90 & 10.43 & 2.18 & 0.44 to 10.74 \\
\hline 11 & Lumber and wood products & 5 & 12.15 & 6.54 & 1.19 & 0.29 to 4.99 \\
\hline 12 & Metal industries & 17 & 12.13 & 3.91 & 1.47 & 0.70 to 3.11 \\
\hline 14 & Electrical machinery, equipment, and supplies & 21 & 15.65 & 3.97 & 2.25 & 1.02 to 4.95 \\
\hline 15 & Transportation equipment & 16 & 15.68 & 4.48 & 2.05 & 0.75 to 5.61 \\
\hline 17 & Trucking and transportation & 21 & 13.35 & 3.93 & 1.51 & 0.72 to 3.18 \\
\hline 19 & Communications & 5 & 14.51 & 6.85 & 2.07 & 0.66 to 6.48 \\
\hline 20 & Utilities & 5 & 12.69 & 7.72 & 1.55 & 0.34 to 7.08 \\
\hline 21 & Wholesale & 21 & 12.45 & 3.16 & 1.49 & 0.71 to 3.13 \\
\hline 23 & Retail & 41 & 11.78 & 2.39 & 1.44 & 0.76 to 2.74 \\
\hline 27 & Eating and drinking places & 25 & 10.38 & 3.08 & 1.13 & 0.45 to 2.84 \\
\hline 31 & Business services & 11 & 4.54 & 1.46 & 0.53 & 0.27 to 1.04 \\
\hline 32 & Repair services & 9 & 27.61 & 7.65 & 3.35 & 1.35 to 8.33 \\
\hline 33 & Private households & 4 & 11.29 & 7.97 & 1.65 & 0.34 to 8.06 \\
\hline 34 & Lodging places & 7 & 22.04 & 9.90 & 4.10 & 1.39 to 12.14 \\
\hline 35 & Personal services & 4 & 6.59 & 4.33 & 0.84 & 0.19 to 3.65 \\
\hline 36 & Entertainment and recreation services & 5 & 14.27 & 6.89 & 2.32 & 0.77 to 6.92 \\
\hline 37 & Health related & 37 & 10.42 & 2.45 & 1.38 & 0.62 to 3.09 \\
\hline 40 & Educational services & 29 & 7.33 & 1.92 & 1.16 & 0.59 to 2.27 \\
\hline 43 & Justice, public order, and safety & 3 & 4.75 & 4.14 & 0.50 & 0.07 to 3.40 \\
\hline
\end{tabular}

were 1.69 (95\% CI 0.74 to 3.88 ) for work related asthma and 1.46 (95\% CI 0.95 to 2.26 ) for work related wheezing. The PAR estimated by industry was $36.5 \%$ for work related asthma and $28.5 \%$ for work related wheezing.

\section{DISCUSSION}

This study analyzed the data from the NHANES III to determine the prevalence and risk factors of work related asthma and work related wheezing and to define industries at risk in the adult United States population.

There were certain limitations in this study. The working definitions of work related asthma and work related wheezing used in this study, have not previously been validated. For several industries, we were not able to assess the risk reliably, as indicated by wide $95 \%$ CIs, due to few cases. It is possible that workers self selected themselves out of the industries where exposures may worsen their asthmatic symptoms. This healthy worker effect is a common problem in all cross sectional epidemiological studies. We tried to minimise this effect by using longest industry worked in our analysis. There were about 3500 subjects who, in response to the question on work related conjunctivitis, rhinitis, and asthma (item HAL14D), reported that they were not working at the time of interview. Further analysis of these subjects indicated that a high proportion of them reported medically diagnosed asthma and wheezing. It is possible that these subjects left their job or stopped working because of their asthma and represent serious cases, which would have resulted in an underestimation of the prevalence of work related asthma and wheezing in this analysis. Many comparisons were made in our analysis; therefore it is possible that some of our results may have been due to chance alone. There is a paucity of empirical research in which analysis has been by industrial group, which limited our comparisons with the literature. Our analysis was limited to use of the self reported industrial group, collapsed into categories, and was used as a surrogate measure of workplace exposure. This further limited our ability to compare directly the findings with others reported in the literature for certain industrial groups. Finally, the definition used for atopy may have also led to some misclassification, as some atopic people may not have had symptoms of hay fever. Given the strength of the association found, however, between this measure of atopy and both work related asthma and work related wheezing, the influence of this misclassification is likely to have been small.

The prevalence of work related asthma was 3.7\%, whereas $11.5 \%$ of survey respondents reported work related wheeze. These rates are within the wide range reported in various countries. $^{379-1122}$ The PAR estimates were $36.5 \%$ for work related asthma and $27 \%$ for work related wheezing, suggesting that an estimated $27 \%-37 \%$ of cases of work related asthma and wheezing in the NHANES III adult study population would have been prevented if exposures encountered in the at risk industries were eliminated, assuming that the exposure is causally related to the disease. These figures are within the range reported in earlier population based studies, ${ }^{72} 13$ but higher than those reported in studies from various other industrialised countries. ${ }^{22-24}$ Blanc and Toren, ${ }^{13}$ in a recent review of 43 attributable risk estimates from various countries, found that the estimates of attributable risk of asthma due to occupational exposures varied from $2 \%$ to $33 \%$ (median, 15\% in high quality studies).

The higher estimates of PAR found in our analysis could be due to several reasons, including differences in study population and case definitions used to define work related asthma or the approach used to classify industries. Alternately, the lower PAR reported in other countries may reflect true differences in industrial and occupational exposures encountered in those regions.

This study identified several industrial groups that were associated with work related asthma and work related wheezing. An increased risk of work related asthma or work related wheezing was found in agriculture, forestry and fishing; entertainment industry; educational services; construction; textile mill products; electrical machinery, equipment, and supplies; repair services; and lodging places.

A more than two-fold increased risk of work related asthma and wheeze was identified for the agriculture, forestry, and 
fishing industry. Working in the agriculture sector is associated with numerous occupational health hazards. This industrial group includes farmers and poultry workers, among others, with potential exposures to various respiratory irritants and potential asthmagens including organic dust, numerous organic chemicals-for example, insecticides, biocides, fertilisers-various plant antigens, and various other chemicals. ${ }^{16}$ Several studies have reported an increased risk of asthma and asthmatic symptoms among agriculture workers including farmers, poultry workers, and grain elevator workers. Farmers were reported to have a similarly high risk of asthma in Spain (OR 3.81), New Zealand (OR 4.16), and other industrialised countries. ${ }^{102}$ Farmers accounted for about half of reported cases of occupational asthma in Finland in 1990. ${ }^{25}$ Poultry workers have also been shown to have an increased risk of work related asthma and asthmatic symptoms ${ }^{26} 27$ and significantly lower lung function values. ${ }^{28}$ Similarly, increases in the prevalence of asthma have also been reported among grain elevator workers. ${ }^{29}$ The consistently increased risk found among agricultural workers in earlier studies, and the similar results found in this analysis strongly suggest a causal association between agricultural exposures and asthma.

A three-fold increased risk for work related wheezing, but not work related asthma, was found for the construction industrial group. Construction is one of the largest industries in the United States. Workers in the construction industry may be exposed to increased concentrations of construction dust, wood dust, various paints, asphalt, and dust from concrete and masonry, as well as gases and vapours. Few population based studies have reported similar associations in this industry $y^{17}{ }^{30}$; others found no such association. ${ }^{22}{ }^{24}$ It is possible that the risk of asthma varies within the construction industry and the choice of study population may in part be responsible for the inconsistency found in the results. In the construction industry, exposure to wood dust has been reported to be associated with increased risk of asthma. ${ }^{31} 32$ We did not find any association with work related asthma. This could partly be due to the healthy worker effect, as subjects with asthma may tend to avoid working in the dusty trades. Alternately, work related wheezing could be due to conditions other than asthma-for example, chronic bronchitis or emphysema. However, we adjusted our analysis for smoking, which may have diminished the effect if any. Although we did not find an increased risk for work related asthma, the significantly increased risk found with work related wheeze suggests that workers in the construction industry may be at a greater risk than reported in earlier studies.

A two-fold increased risk of work related wheeze, but not work related asthma, in the textile industrial group was found in this analysis. Workers in a textile industry are potentially exposed to cotton and other fibre dusts, textile dyes, and fabric printing and treatment chemicals. Textile workers have often been reported to have an excess risk of asthma. ${ }^{173}$ In a community based case-control study of risk factors of work related asthma in different occupational groups in Singapore, $\mathrm{Ng}$ et $a l^{17}$ reported more than a five-fold increased risk of asthma among textile workers. In a study by Zuskin et al, , $^{33}$ occupational asthma was present among $6 \%$ of workers exposed to textile dye. These same authors, in another study, reported significant changes in pulmonary function indices across the shift among synthetic textile workers. ${ }^{34}$ Some workers may also have been exposed to cotton dust, which can cause byssinosis, a condition clinically similar to asthma.

Risk in the industrial group electrical machinery, equipment, and supplies is less well recognised. Our study found a twofold increase in the risk of work related asthma and wheezing in this industrial group. The results, however, were significant only for work related wheeze. The industries included in this group are involved in processes with potential for exposure to several irritants and allergens including metal machining fluids, lubricants, solvents, paints and coatings, adhesives, soldering fluxes, and various chemicals used in semiconductor manufacturing. Several case reports have described the development of occupational asthma from exposure to fumes generated from soldering flux. ${ }^{35}{ }^{36}$ However, in a cross sectional study of female workers doing manual soldering with flux cored solder wire and using administrative staff as controls, Lee $e t a^{37}$ did not find any increase in the prevalence of asthmatic symptoms, nor did they detect any cases of occupational asthma. Workers with 5 or more years of experience, however, had a significant reduction in the ratio between forced expiratory volume in 1 second and forced vital capacity $\left(\mathrm{FEV}_{\mathrm{l}} / \mathrm{FVC}\right)$. McCurdy et $\mathrm{al}^{38}$ in a large cross sectional survey of semiconductor workers, reported a significantly increased risk of persistent wheezing among fabrication workers. Several case reports have described exposures to adhesives - for example, cyanoacrylates-associated with occupational asthma. ${ }^{39}$ However, in a large occupational cohort of 450 workers, exposure to cynacrylates was not found to be associated with asthma, using $\mathrm{FEV}_{1} / \mathrm{FVC}<70 \%$ as the criterion for case definition. ${ }^{41}$ Although it was not our intent to comprehensively review all possible exposures that may occur in the electrical machinery, equipment, and supplies industry, neither is it possible to determine what the actual individual exposures were, although we can reason that the potential for exposure to asthmagens is high in this group, or at least in subpopulations within the group, and the findings from this analysis could benefit from additional study.

A strong association between work related asthma and wheeze and the repair industrial group was found in this analysis. Workers in this industrial group include vehicle mechanics who are at increased risk of exposures to several agents including spray paints, degreasing solvents, and welding fumes. Spray paints may contain various isocyantes,well known to cause allergy mediated occupational asthma. ${ }^{30}$ Welding fumes contain a complex mixture of particulate material and gases and are strong respiratory irritants. Welders have been shown to experience an accelerated annual decline in $\mathrm{FEV}_{1}^{43}$ which may possibly lead to permanent respiratory impairment. In a study by Kogevinas et al, ${ }_{10}^{10}$ welders showed a significantly increased risk of asthma. Similarly, exposure to welding fumes was associated with a two-fold increased risk of asthma among Swedish workers, consistent with the findings of our study. ${ }^{23}$ These earlier data, combined with the results from this study, support a causal association between potential exposures encountered in this industrial group and asthma.

A four-fold increased odds of association between employment in the lodging industry with work related wheezing was found in this analysis. The exposures of concern in the lodging industry are mostly related to cleaning substances, which include solvents, sensitisers, and other volatile compounds. The risk of asthma among cleaners is not well established. In a study prompted by a case report of occupational asthma in a detergent industry, Vanhanen $\mathrm{et}^{\mathrm{l} \mathrm{l}^{44}}$ reported a prevalence of sensitisation to enzymes as $22 \%$ among workers exposed to detergent enzymes. In a prospective study by Nielsen and Bach, ${ }^{45}$ female cleaners were found to have high risk of developing respiratory symptoms. Few population based studies have reported an increased risk of asthma among cleaners. In a study by Kogevinas et $a l^{10}$ a greater than two-fold increased risk of asthma among cleaners was reported. Recently, in a multicountry population based study, based on the European Community respiratory health survey, the same authors reported an increased OR of asthma as high as 4.50 among cleaners, similar to the results reported in our study. The risk was consistent across different countries. ${ }^{22}$ A similar excess risk of asthma among cleaners was also reported by $\mathrm{Ng}$ et al in Singapore. ${ }^{17}$ The present evidence in the literature and strong association found in our study suggests that cleaners are at a high risk of developing occupational asthma.

This study found more than a five-fold increase in the risk of work related asthma in the entertainment industry. This group, which includes artists, designers, and photographers, 
has rarely been studied before. It includes workers with potential exposures to chemicals used in art media, stage set production, theatrical make up and photographic chemicals. ${ }^{46}$ In a community based study Forastiere et $a l^{47}$ reported an increased risk of adult asthma among women in occupations related to entertainment. Nakano $e t$ al $^{48}$ recently described a case of occupational asthma resulting from exposure to pyrazolone dye used in silver halide photographic paper. Given the paucity of reports in the literature, our results suggest that this association could benefit from further studies.

Analysis from this study also found an increased risk of work related asthma in workers in the educational services. Asthma among teachers has not been studied before. Teachers are more likely to be exposed to environmental indoor allergens, which can be strong risk factors for asthma. ${ }^{49}$ Alternately, the increased risk found in this analysis could reflect self selection of subjects with asthma into this occupation. However, further studies are needed to determine whether the associations found are real or just a random finding.

In conclusion, findings from this population based study indicate that several industries are associated with an increased risk of work related asthma and work related wheezing and that $27 \%$ to $37 \%$ of the work related asthma and wheeze is attributable to selected at risk industrial groups. Most of the risks in this analysis were consistent with findings from other population based studies. Our findings provide impetus for further research and actions which prioritise OA on the public health agenda.

\section{Authors' affiliations}

A A Arif, L W Whitehead, G L Delclos, S R Tortolero, E S Lee, University of Texas-Houston Health Science Center, School of Public Health, Houston, TX-77030, USA

\section{REFERENCES}

1 Chan-Yeung $\mathbf{M}$, Malo JL. Aetiologic agents in occupational asthma. Eur Respir J 1994;7:346-71.

2 de la Hoz RE, Young RO, Pedersen DH. Exposure to potential occupational asthmogens: prevalence data from the national occupational exposure survey. Am J Ind Med 1997;31:195-201.

3 Meridith SK, Taylor VM, McDonald JC. Occupational respiratory disease in the United Kingdom 1989: a report to the British Thoracic Society and the Society of Occupational Medicine by the SWORD project group. Br J Ind Med 1991;48:292-8.

4 Contreras GR, Rousseau R, Chan-Yeung M. Occupational respiratory diseases in British Columbia, Canada in 1991. Occup Environ Med 1994;51:710-2

5 Gannon PF, Burge PS. The SHIELD scheme in the West Midlands Region, United Kingdom. Midland Thoracic Society Research Group. Br J Ind Med 1993;50:791-6.

6 United States Department of Health and Human Services. National occupational research agenda. Cincinatti: DHHS (NIOSH), 1996. (Publ No 96-115.

7 Milton DK, Solomon GM, Rosiello RA, et al. Risk and incidence of asthma attributable to occupational exposure among $\mathrm{HMO}$ members. Am J Ind Med 1998;33:1-10.

8 Centers for Disease Control and prevention. Asthma surveillance programs in public health departments United States. Mor Mortal Wkly Rep CDC Surveill Summ 1996:45.

9 Blanc P. Occupational asthma in national disability survey. Chest 1987;92:613-7

10 Kogevinas M, Anto JM, Soriano JB, et al. The risk of asthma attributable to occupational exposures. A population- based study in Spain. Spanish Group of the European Asthma Study. Am J Respir Crit Care Med $1996 ; 154: 137-43$

11 Reijula K, Haahtela T, Klaukka T, et al. Incidence of occupational asthma and persistent asthma in young adults has increased in Finland. Chest 1996;110:58-61.

12 Johnson AR, Dimich-Ward HD, Manfreda J, et al. Occupational asthma in adults in six Canadian communities. Am J Respir Crit Care Med 2000;162:2058-62

13 Blanc PD, Toren K. How much adult asthma can be attributed to occupational factors? Am J Med 1999;107:580-7.

14 Mapp CE, Boschetto P, Dal Vecchio L, et al. Occupational asthma due to isocyanates. Eur Respir J 1988;1:273-9.

15 Bherer L, Cushman R, Courteau JP, et al. Survey of construction worker repeatedly exposed to chlorine over a 3 to 6 month period in a pulpmill: II. Follow up of affected workers by questionnaire, spirometry, and assessment of bronchial responsiveness 18 to 24 months after exposure ended. Occup Environ Med 1994;51:225-8.
16 Chan-Yeung M. Occupational asthma [review]. Chest 1990:98:148S-61S

17 Ng TP, Hong CY, Goh LG, et al. Risks of asthma associated with occupations in a community-based case-control study. Am J Ind Med 1994; 25:709-18.

18 Hook WA, Powers K, Siraganian RP. Skin tests and blood leukocyte histamine release of patients with allergies to laboratory animals. J Allergy Clin Immunol 1984;73:457-65

19 Vandenplas O, Delwiche JP, Evrard G, et al. Prevalence of occupational asthma due to latex among hospital personnel. Am J Respir Crit Care Med 1995; 151:54-60

20 National Center for Health Statistics. Plan and operation of the third national health and nutrition examination survey, 1988-94. National Center for Health Statistics 1994;1:32.

21 United States Bureau of the Census. 1980 census of population: classified index of industries and occupations. Washington, DC: USBC, 1982. (PHC80-R4.)

22 Kogevinas M, Anto JM, Sunyer J, et al. Occupational asthma in Europe and other industrialised areas: a population based study. European Community Respiratory Health Survey Study Group. Lancet 1999;353:1750-4.

23 Toren K, Jarvholm B, Brisman J, et al. Adult onset asthma and occupational exposures. Scand J Work Environ Health 1999:25:430-5.

24 Fishwick D, Pearce N, D'Souza W, et al. Occupational asthma in New Zealanders: a population based study. Occup Environ Med 1997;54:301-6.

25 Nordman H, Karjalainen A, Keskinen H. Incidence of occupational asthma: a comparison by reporting systems. Am J Ind Med 1999;(suppl 1):130-3

26 Magarolas R, Monso E, Aguilar X, et al. Prevalence and risk factors of respiratory symptoms in farmers; comment. Med Clin (Barc) 2000;114:685-9.

27 Rees D, Nelson G, Kielkowski D, et al. Respiratory health and immunological profile of poultry workers. S Afr Med J 1998;88:1110-7.

28 Zuskin E, Mustajbegovic J, Schachter EN, et al. Respiratory function in poultry workers and pharmacologic characterization of poultry dust extract. Environ Res 1995;70:11-9.

29 Siracusa A, Kennedy SM, DyBuncio A, et al. Prevalence and predictors of asthma in working groups in British Columbia. Am J Ind Med 1995;28:411-23.

30 Meredith SK, McDonald JC. Work related respiratory disease in the United Kingdom, 1989-92: report on the SWORD project. Occup Med (Lond) 1994;44:183-9.

31 Hessel PA, Herbert FA, Melenka LS, et al. Lung health in sawmill workers exposed to pine and spruce. Chest 1995;108:642-6.

32 Norrish AE, Beasley R, Hodgkinson EJ, et al. A study of New Zealand wood workers: exposure to wood dust, respiratory symptoms, and suspected cases of occupational asthma. N Z Med J 1992;105:185-7.

33 Zuskin E, Mustajbegovic J, Schachter EN, et al. Respiratory function of textile workers employed in dyeing cotton and wool fibers. Am J Ind Med 1997;31:344-52.

34 Zuskin E, Mustajbegovic J, Schachter EN, et al. Respiratory findings in synthetic textile workers. Am J Ind Med 1998;33:263-73.

35 Fawcett IW, Taylor AJ, Pepys J. Asthma due to inhaled chemical agents: fumes from "Multicore" soldering flux and colophony resin. Clin Allergy 1976;6:577-85

36 Weir DC, Robertson AS, Jones S, et al. Occupational asthma due to soft corrosive soldering fluxes containing zinc chloride and ammonium chloride. Thorax 1989:44:220-3.

37 Lee HS, Koh D, Chia HP, et al. Symptoms, lung function, and diurnal variation in peak expiratory flow rate among female solderers in the electronics industry. Am J Ind Med 1994;26:613-9.

38 McCurdy SA, Pocekay D, Hammond SK, et al. A cross-sectional survey of respiratory and general health outcomes among semiconductor industry workers. Am J Ind Med 1995:28:847-60.

39 Lozewicz S, Davison AG, Hopkirk A, et al. Occupational asthma due to methyl methacrylate and cyanoacrylates. Thorax 1985;40:836-9.

40 Chan CC, Cheong TH, Lee HS, et al. Case of occupational asthma due to glue containing cyanoacrylate. Ann Acad Med Singapore 1994:23:731-3.

41 Goodman M, Paustenbach D, Sipe K, et al. Epidemiologic study of pulmonary obstruction in workers occupationally exposed to ethyl and methyl cyanoacrylate. J Toxicol Environ Health 2000;59:135-63.

42 Franklin PJ, Goldenberg WS, Ducatman AM, et al. Too hot to handle: an unusual exposure of $\mathrm{HDI}$ in specialty painters. Am J Ind Med 2000;37:431-7.

43 Erkinjuntti-Pekkanen R, Slater T, Cheng S, et al. Two year follow up of pulmonary function values among welders in New Zealand. Occup Environ Med 1999;56:328-33.

44 Vanhanen $M$, Tuomi T, Tiikkainen U, et al. Risk of enzyme allergy in the detergent industry. Occup Environ Med 2000;57:121-5.

45 Nielsen J, Bach E. Work-related eye symptoms and respiratory symptoms in female cleaners. Occup Med (Lond) 1999;49:291-7.

46 Rossol M. Stage Fright: Health and safety in the Theater. New York: Alworth Press, 1991

47 Forastiere $\mathbf{F}$, Balmes J, Scarinci $M$, et al. Occupation, asthma, and chronic respiratory symptoms in a community sample of older women. Am J Respir Crit Care Med 1998;157:1864-70.

48 Nakano Y, Tsuchiya T, Hirose K, et al. Occupational asthma caused by pyrazolone derivative used in silver halide photographic paper. Chest 2000;1 18:246-8

49 Pearce N. Asthma epidemiology: principles and methods. New York: Oxford University Press, 1998. 